\title{
Multistep electron transfer catalytic system for the oxidative carbonylation of phenol to diphenyl carbonate
}

\author{
Andrea Vavasori, Luigi Toniolo * \\ Department of Chemistry, University of Venice, Dorsoduro 2137, 30123 Venice, Italy
}

Received 25 February 1998; accepted 14 May 1998

\begin{abstract}
The oxidative carbonylation of phenol to diphenyl carbonate is catalyzed by palladium salts in combination with a cocatalyst such as $p$-benzoquinone (BQ) or a salt of $\mathrm{Co}, \mathrm{Mn}, \mathrm{Cu}$. The addition of a surfactant such as tetrabutylammonium bromide makes the catalytic system more efficient. The role of each component in the catalytic system is discussed. A catalytic cycle is proposed where, in the first step, diphenylcarbonate is formed from phenol and $\mathrm{CO}$ with concomitant reduction of $\mathrm{Pd}(\mathrm{II})$ to $\mathrm{Pd}(0)$ and formation of two protons. $p$-Benzoquinone, which is reduced to hydroquinone, in the presence of protons, reoxidizes $\mathrm{Pd}(0)$ to $\mathrm{Pd}(\mathrm{II})$ while the metal cocatalyst is reduced by hydroquinone which is reoxidized to $p$-benzoquinone. Oxygen and protons, arising from the last reaction, close the cycle with reoxidation of the reduced metal cocatalyst and formation of water. (C) 1999 Published by Elsevier Science B.V. All rights reserved.
\end{abstract}

Keywords: Multistep electron transfer catalytic system; Oxidative carbonylation; $p$-Benzoquinone

\section{Introduction}

Aromatic carbonates have come to occupy an important position as useful organic chemicals for a variety of industrial and synthetic applications. They are used as solvents and as reagents in the transesterification reactions with glycols and bisphenols for the production of polycarbonates, as chemical intermediates and potential gasoline additives [1].

The industrial methods which are most commonly employed for the synthesis of aryl carbonates are based on the reaction between an alkanol with phosgene in the presence of bases.

Because the current trend in the chemical industry is to reduce the risks connected with the use of highly toxic substances such as phosgene [2], alternative approaches to diphenyl carbonate (DPC) production appear to be both the carbonate interchange reaction of aromatic hydroxy compounds with dimethyl carbonate or the oxidative carbonylation of the corresponding phenol [1-4].

Palladium compounds are able to promote easily the noncatalytic carbonylation [5-8] and the catalytic (in the presence of a cocatalyst) oxidative carbonylation of methanol to produce dimethyl carbonate $[9,10]$, however the analogous reactions with phenol to DPC are not so efficient because of

\footnotetext{
* Corresponding author. Tel.: +39-41-527-8553; Fax: +39-41-527-8517
} 
the lower basicity of phenols and the ease of phenol oxidation which leads to several side reactions $[11,12]$. In the presence of a tertiary amine, palladium carbonyl chloride reacts with phenol to DPC in a lower than stoichiometric yield [10]. It has also been reported that $\mathrm{Pd}(\mathrm{II})$ acetate is readily reduced to $\mathrm{Pd}(0)$ complexes by $\mathrm{CO}(1 \mathrm{~atm})$ in a phenol solution at $50^{\circ} \mathrm{C}$ to give $\mathrm{CO}_{2}$ and phenyl acetate and that, when the reaction is carried out in the presence of $\mathrm{O}_{2}$, formation of DPC is observed [13,14].

If $\mathrm{Pd}(0)$ can be reoxidized to $\mathrm{Pd}(\mathrm{II})$, a catalytic cycle would become operative. To speed up the oxidation, a multistep electron transfer system has to be used [15]. In these systems, in the presence of an excess of bromide salt, continuous regeneration in situ of $\operatorname{Pd}(\mathrm{II})$ from $\operatorname{Pd}(0)$ by an oxidant (typically, copper, cobalt or manganese salts or $p$-benzoquinone (BQ) [16-21]) is the key step for the efficient catalytic oxidation.

The methods mentioned in the literature [15-20] for making $\mathrm{DPC}$, using $\mathrm{Pd}(\mathrm{OAc})_{2}$ as catalyst in the presence of cocatalysts, provide effective results.

However, the performances, in terms of productivity and selectivity, are not satisfactory and, in addition, organic solvents are generally employed as well as solid drying agents which can interfere with the recovery of the catalysts. Thus, we undertook a study for the catalytic oxidative carbonylation of phenol to DPC in order to better understand the role of each component the catalytic system and to make it more efficient.

\section{Experimental}

\subsection{Materials}

Carbon monoxide and oxygen, supplied by SIAD Spa (Italy), have a purity higher then $99 \%$. Phenol 99\%, biochemical grade, tetrabutylammonium bromide (TBAB) 99\% and 1,4 benzoquinone (BQ) 99\% were purchased from Acros Chemicals. $\mathrm{Pd}(\mathrm{OAc})_{2}$ 98\%, $\mathrm{PdCl}_{2} \quad 99 \%, \mathrm{PdBr}_{2}$, $\mathrm{Pd}\left(\mathrm{CH}_{3} \mathrm{CN}\right)_{2} \mathrm{Cl}_{2}, \mathrm{Co}(\mathrm{acac})_{3} 98 \%, \mathrm{Co}(\mathrm{OAc})_{2} \cdot 4 \mathrm{H}_{2} \mathrm{O}, \mathrm{Mn}(\mathrm{acac})_{3}, \mathrm{Cu}(\mathrm{OAc})_{2}$ and $\mathrm{Cu}(\mathrm{acac})_{2} 99 \%$, were purchased from Aldrich Chemicals. Other cobalt complexes used were prepared according to literature methods [22,23].

\subsection{Experimental setup}

All the experiments were carried out in a stainless steel autoclave of ca. $100 \mathrm{ml}$ of capacity, provided with a magnetic stirrer. The reaction occurred in a ca. $70 \mathrm{ml}$ Pyrex glass beaker placed into the autoclave in order to prevent contamination by metallic species due to corrosion of the internal surface of the autoclave.

In order to monitor the consumption of carbon monoxide and oxygen, a gas reservoir was used along with a constant pressure regulator. This equipment was provided with a temperature control $\left( \pm 0.5^{\circ} \mathrm{C}\right)$ and sampling of the gas phase.

\subsection{Experimental procedure}

Typical reaction conditions were: $T=100^{\circ} \mathrm{C}, P=60 \mathrm{~atm}\left(\mathrm{CO} / \mathrm{O}_{2}=10 / 1\right.$ molar ratio $)$, phenol $=$ $80 \mathrm{mmol}$ (reagent and solvent in these reactions), $\mathrm{Pd} /$ metal cocatalyst $/ p$-benzoquinone $=1 / 2 / 30$ molar ratio, $\mathrm{Pd}(\mathrm{OAc})_{2}=0.01 \mathrm{mmol}$, reaction time $5 \mathrm{~h}$. In addition to the cocatalyst, a soluble bromide salt, such as tetrabutylammonium bromide (TBAB) $(\mathrm{Pd} / \mathrm{TBAB}=1 / 60$ molar ratio) was added to the reaction mixture. In a typical experiment, known quantities of the catalyst, cocatalyst, 
BQ and TBAB along with the solvent (phenol) where charged into a glass bottle introduced inside the autoclave. Then the autoclave was pressurized with the mixture of carbon monoxide and oxygen. All the experiments were carried out using the two gases in the ratio 10/1 to make sure to operate with a safe nonexplosive oxygen containing gas mixture. At the end of the reaction the autoclave was cooled to room temperature and vented.

Products were characterized by GC analysis on a HP 5890 series II instrument equipped with a 30 $\mathrm{m} \times 0.53 \mathrm{~mm} \times 0.1 \mu \mathrm{m}$ FFAP column. The gas phase products $\left(\mathrm{CO} / \mathrm{CO}_{2}\right.$ molar ratio $)$ were analyzed by GC using an $18 \mathrm{ft} \times 1 / 8$ SS Silica Gel, 60/80 packed column.

\section{Results and discussion}

\subsection{Oxidative carbonylation}

The oxidative carbonylation of phenol is schematized by reaction (1):

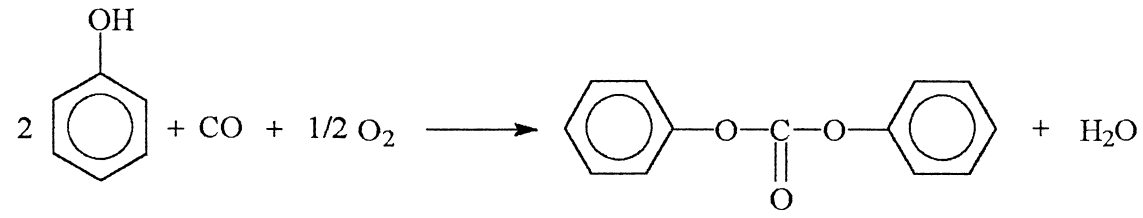

This reaction needs the presence of a catalyst in order to obtain diphenyl carbonate (DPC). We studied the efficiency of a palladium-based catalyst. The reaction occurs with formation of by-products that include the oxidative dimerization and trimerization products such as $p$-phenoxyphenol, phenylsalicylate and oligomeric compounds. In addition, carbon monoxide is consumed also by the reaction with oxygen to carbon dioxide, which is catalyzed also by palladium compounds.

\subsection{Catalytic system}

\subsubsection{Palladium complexes as catalyst}

In Table 1, the productivities obtained with different $\mathrm{Pd}(\mathrm{II})$ complexes, under the same experimental conditions (without the addition of any cocatalyst), are reported.

Table 1

Pd(II) compounds tested as catalysts for the oxidative carbonylation of phenol to DFC

\begin{tabular}{rlll}
\hline Entry & Catalyst & $\begin{array}{l}\text { Time } \\
(\mathrm{h})\end{array}$ & $\begin{array}{l}\text { DPC } \\
(\mathrm{mol} / \mathrm{mol} \mathrm{Pd})\end{array}$ \\
\hline 1 & & 4 & 0.5 \\
2 & $\mathrm{Pd}(\mathrm{OAc})_{2}$ & 5 & 0.6 \\
3 & $\mathrm{PdBr}_{2}$ & 6 & trace \\
4 & $\mathrm{PdCl}_{2}$ & 5 & 0.2 \\
5 & $\mathrm{PdCl}_{2}\left(\mathrm{PPh}_{3}\right)_{2}$ & 3 & 0.1 \\
6 & $\mathrm{Pd}\left(\mathrm{CH}_{3} \mathrm{CN}_{2} \mathrm{Cl}_{2}\right.$ & 3 & 0.1 \\
7 & $\mathrm{Pd}(\mathrm{picO})_{2}$ & 3 & 0.2 \\
8 & $\mathrm{Pd}(\text { pic })_{2}$ & 5 & trace \\
9 & $\mathrm{Pd}(\mathrm{phen})(\mathrm{OAc})_{2}$ & 4 & 0.4 \\
10 & $\mathrm{Pd}(\text { benz })_{2}$ & 6 & 0.2 \\
\hline
\end{tabular}

$\mathrm{Pd}(\mathrm{II})=0.01 \mathrm{mmol} ; \mathrm{PhOH}=80 \mathrm{mmol} ; T=100^{\circ} \mathrm{C} ; P=60 \mathrm{~atm}\left(\mathrm{CO} / \mathrm{O}_{2}=10 / 1\right)$. 
Reaction (1) is promoted by $\mathrm{Pd}(\mathrm{II})$ compounds but the DPC is not obtained in a catalytic amount. At the end of each experiment, palladium metal was found to be present in significant amount. This suggests that the formation of DPC occurs at the expenses of the reduction of the starting Pd(II) complex and that, under these conditions, oxygen is not able to reoxidize reduced palladium to a $\mathrm{Pd}(\mathrm{II})$ species, thus preventing the reaction to be catalytic:

$$
2 \mathrm{PhOH}+\mathrm{CO}+\mathrm{Pd}^{2+} \rightarrow \mathrm{PhOCOOPh}+\mathrm{Pd}_{\mathrm{met}}+2 \mathrm{H}^{+} .
$$

\subsubsection{Redox agents as cocatalysts}

In order to make the reaction catalytic, it is necessary to introduce a suitable redox cocatalyst, able to ease the oxidation of reduced palladium. The results reported in Table 2 show that in the presence of redox systems based on $\mathrm{Cu}, \mathrm{Co}, \mathrm{Mn}$ salts, which are not catalysts for reaction (1) (entries 1-3), DPC is obtained in a catalytic amount (entries 4-6, 11-13). Also, BQ alone can be an effective reoxidation agent (entries 7, 14), however, in this case, the T.O.N. is low (4 and $5.5 \mathrm{~mol} \mathrm{DPC} / \mathrm{mol}$ $\mathrm{Pd}$ ). On the other hand, when $\mathrm{BQ}$ is added to a $\mathrm{Pd} /$ metal cocatalyst system (entries 8-10, 15-17), the productivity is increased further, confirming that BQ plays an important role in the catalytic cycle. The highest productivity is obtained using $\mathrm{PdBr}_{2}$, in combination with a $\mathrm{Cu}$ salt and BQ (18.3 mol $\mathrm{DPC} / \mathrm{mol} \mathrm{Pd}$, entry 17). It is known [24] that BQ acts also as a ligand and prevents effectively the aggregation of $\mathrm{Pd}$ metal by the formation of BQ-Pd complexes which are easily transformed to the active $\mathrm{Pd}(\mathrm{II})$ complex by the metal redox agent. However, also in this set of experiments, the reoxidation step was not so efficient as $\mathrm{Pd}$ metal was found at the end of each reaction. Accordingly, a low turnover number was observed.

Table 2

Effect of the addition of a metal and or an organic (BQ) redox agent, as cocatalyst, on the productivity

\begin{tabular}{|c|c|c|c|c|}
\hline Entry & Catalyst & Cocatalyst & $\begin{array}{l}\text { Time } \\
\text { (h) }\end{array}$ & $\begin{array}{l}\mathrm{DPC} \\
(\mathrm{mol} / \mathrm{mol} \mathrm{Pd})\end{array}$ \\
\hline 1 & - & $\mathrm{Co}(\mathrm{OAc})_{2}$ & 3 & trace \\
\hline 3 & - & $\mathrm{Cu}(\mathrm{OAc})_{2}$ & 5 & 0.1 \\
\hline 4 & $\mathrm{Pd}(\mathrm{OAc})_{2}$ & $\mathrm{Co}(\mathrm{OAc})_{2}$ & 4 & 3.2 \\
\hline 5 & $\mathrm{Pd}(\mathrm{OAc})_{2}$ & $\operatorname{Mn}(\mathrm{acac})_{3}$ & 5 & 2.3 \\
\hline 8 & $\mathrm{Pd}(\mathrm{OAc})_{2}$ & $\mathrm{Co}(\mathrm{OAc})_{2}+\mathrm{BQ}$ & 5 & 8.0 \\
\hline 9 & $\mathrm{Pd}(\mathrm{OAc})_{2}$ & $\mathrm{Mn}(\mathrm{acac})_{3}+\mathrm{BQ}$ & 4 & 5.1 \\
\hline 10 & $\mathrm{Pd}(\mathrm{OAc})_{2}$ & $\mathrm{Cu}(\mathrm{OAc})_{2}+\mathrm{BQ}$ & 4 & 8.2 \\
\hline 11 & $\mathrm{PdBr}_{2}$ & $\mathrm{Co}(\mathrm{OAc})_{2}$ & 5 & 8.3 \\
\hline 12 & $\mathrm{PdBr}_{2}$ & $\operatorname{Mn}(\mathrm{acac})_{3}$ & 5 & 5.1 \\
\hline 17 & $\mathrm{PdBr}_{2}$ & $\mathrm{Cu}(\mathrm{OAc})_{2}+\mathrm{BQ}$ & 5 & 18.3 \\
\hline
\end{tabular}

$\mathrm{Pd}(\mathrm{II})=0.01 \mathrm{mmol} ; \mathrm{PhOH}=80 \mathrm{mmol} ;$ metal cocatalyst $/ \mathrm{Pd}(\mathrm{II})=3 / 1(\mathrm{~mol} / \mathrm{mol}) ; p$-BQ $/ \mathrm{Pd}=30 / 1(\mathrm{~mol} / \mathrm{mol}) ; T=100^{\circ} \mathrm{C} ; P=60 \mathrm{~atm}$ $\left(\mathrm{CO} / \mathrm{O}_{2}=10 / 1\right)$. 


\subsubsection{Multistep electron transfer catalytic cycle}

According to the results reported in Tables 1 and 2, the proposed catalytic cycle, is schematized in Eqs. (3)-(6).

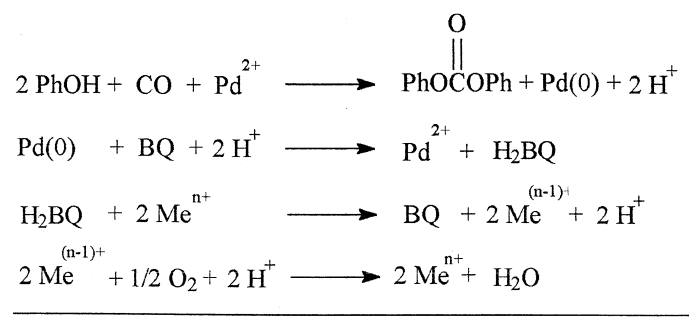

$2 \mathrm{PhOH}+\mathrm{CO}+1 / 2 \mathrm{O}_{2} \longrightarrow \stackrel{\mathrm{O}}{\|} \mathrm{PhOCOPh}+\mathrm{H}_{2} \mathrm{O}$

where $\mathrm{Me}=\mathrm{Co}, \mathrm{Mn}, \mathrm{Cu} ; \mathrm{H}_{2} \mathrm{BQ}=$ hydroquinone.

In the first step, DPC forms from phenol and $\mathrm{CO}$ with concomitant reduction of $\mathrm{Pd}(\mathrm{II})$ to $\mathrm{Pd}(0)$ and formation of two protons. This reaction is made catalytic by means of a system in which the $\mathrm{Pd}$ reoxidation is mediated by the addition of an organic cocatalyst, $p$-benzoquinone (BQ), and of a metal cocatalyst. It is proposed that $\mathrm{BQ}$, which is reduced to hydroquinone $\left(\mathrm{H}_{2} \mathrm{BQ}\right)$, in the presence of protons, reoxidizes $\mathrm{Pd}(0)$ to $\mathrm{Pd}(\mathrm{II})$ while the metal cocatalyst is reduced (for instance $\mathrm{Co}$ (III)) to $\mathrm{Co}(\mathrm{II})$ ) by $\mathrm{H}_{2}$ BQ which is reoxidized to BQ. Oxygen and protons, arising from the last reaction, close the cycle with reoxidation of the reduced metal cocatalyst and formation of water.

The reoxidation of $\operatorname{Pd}(0)$ to a $\mathrm{Pd}(\mathrm{II})$ species gives rise to a catalytic system, however the productivity obtained is low, probably due to the instability of the $\operatorname{Pd}(0)$ complexes with formation of $\mathrm{Pd}$ metal which is difficult to reoxidize. We try to improve the performance of this catalytic system introducing the soluble tetrabutylammonium bromide (TBAB) salt which is known [15] to act both as stabilizing agents for $\mathrm{Pd}(\mathrm{II})$, and as surfactant agents for $\mathrm{Pd}(0)$ complexes.

\subsubsection{Tetrabutylammonium bromide $(T B A B)$ as surfactant agent}

TBAB is neither a catalyst for reaction (1) (Table 3, entry 1) nor a cocatalyst for the $\operatorname{Pd}(\mathrm{II})$ complex (entries 2-6). However, the addition of TBAB to the catalyst/cocatalyst makes the catalytic cycle more efficient (entries 7-20). In particular, $\mathrm{Pd}(\mathrm{OAc})_{2}$ shows a higher catalytic activity (66 mol $\mathrm{DPC} / \mathrm{mol} \mathrm{Pd} \mathrm{h}$, entry 17) than $\mathrm{PdBr}_{2}$, under the same experimental conditions (50 mol DPC/mol Pd h, entry 20).

Fig. 1 shows that the catalytic activity reaches a plateau $(40 \mathrm{~mol} \mathrm{DPC} / \mathrm{mol} \mathrm{Pd} h)$ when the molar ratio $\mathrm{TBAB} / \mathrm{Pd}$ is larger than $40 / 1$. In any case, when an excess of $\mathrm{TBAB}$ is added, $\mathrm{Pd}$ metal formation is avoided.

The productivity falls down (7 mol DPC/mol Pd h) when a different bromide, such as $\mathrm{LiBr}$, is employed in place of TBAB (entry 21 ).

It is reasonable to suppose that the presence of bromide leads to an in situ formation of a more stable $\mathrm{Pd}(\mathrm{II})$ catalyst of the type $\mathrm{PdBr}_{4}^{2-}$ [13], thus easing the reoxidation step. However, the comparison of the catalyst activity of experiments 17 or 20 with 21 of Table 3 suggests that also the TBAB cation plays an important role, probably due to its surfactant properties. In fact, it is known [25-28] that the chemical reduction of transition metal salts, in the presence of a surfactant such as a tetralkylammonium salt, leads to nanostructured $\mathrm{R}_{4} \mathrm{~N}^{+} \mathrm{X}^{-}$-stabilised metal clusters [25-28]. In these 
Table 3

Effect of TBAB addition on the catalytic system

\begin{tabular}{|c|c|c|c|c|c|}
\hline Entry & Catalyst & Cocatalyst & $\mathrm{mol} \mathrm{DPC} / \mathrm{mol} \mathrm{Pd}$ & time (h) & $\mathrm{mol} \mathrm{DPC} / \mathrm{mol} \mathrm{Pd} \mathrm{h}$ \\
\hline 1 & TBAB & - & trace & 5 & trace \\
\hline 2 & $\mathrm{PdBr}_{2}+\mathrm{TBAB}$ & - & 0.1 & 5 & 0.5 \\
\hline 3 & $\mathrm{Pd}(\mathrm{OAc})_{2}+\mathrm{TBAB}$ & - & 0.1 & 5 & 0.5 \\
\hline 4 & $\mathrm{Pd}($ phen $)(\mathrm{OAc})_{2}+\mathrm{TBAB}$ & - & trace & 5 & trace \\
\hline 5 & $\mathrm{PdCl}_{2}+\mathrm{TBAB}$ & - & trace & 5 & trace \\
\hline 6 & $\mathrm{Pd}(\text { benz })_{2}+\mathrm{TBAB}$ & - & 0.1 & 4 & 0.4 \\
\hline 9 & $\mathrm{Pd}(\mathrm{OAc})_{2}+\mathrm{TBAB}$ & $\mathrm{Cu}(\mathrm{OAc})_{2}$ & 105 & 5 & 21 \\
\hline 10 & $\mathrm{Pd}(\mathrm{OAc})_{2}+\mathrm{TBAB}$ & $p$-BQ & 150 & 5 & 30 \\
\hline 11 & $\mathrm{PdBr}_{2}+\mathrm{TBAB}$ & $\mathrm{Co}(\mathrm{OAc})_{2}$ & 112 & 4 & 15 \\
\hline 12 & $\mathrm{PdBr}_{2}+\mathrm{TBAB}$ & $\operatorname{Mn}(\mathrm{acac})_{3}$ & 60 & 4 & 15 \\
\hline 13 & $\mathrm{PdBr}_{2}+\mathrm{TBAB}$ & $\mathrm{Cu}(\mathrm{OAc})_{2}$ & 120 & 4 & 30 \\
\hline 18 & $\mathrm{PdBr}_{2}+\mathrm{TBAB}$ & $\mathrm{Co}(\mathrm{OAc})_{2}+\mathrm{BQ}$ & 180 & 4 & 45 \\
\hline 19 & $\mathrm{PdBr}_{2}+\mathrm{TBAB}$ & $\mathrm{Mn}(\mathrm{acac})_{3}+\mathrm{BQ}$ & 120 & 4 & 30 \\
\hline 20 & $\mathrm{PdBr}_{2}+\mathrm{TBAB}$ & $\mathrm{Cu}(\mathrm{OAc})_{2}+\mathrm{BQ}$ & 200 & 4 & 50 \\
\hline 21 & $\mathrm{Pd}(\mathrm{OAc})_{2}+\mathrm{LiBr}$ & $\mathrm{Cu}(\mathrm{OAc})_{2}+\mathrm{BQ}$ & 21 & 3 & 7 \\
\hline
\end{tabular}

$\mathrm{Pd}(\mathrm{II})=0.01 \mathrm{mmol} ; \mathrm{PhOH}=80 \mathrm{mmol} ;$ cocatalyst $/ \mathrm{Pd}(\mathrm{II})=3 / 1(\mathrm{~mol} / \mathrm{mol}) ; p-\mathrm{BQ} / \mathrm{Pd}=30 / 1(\mathrm{~mol} / \mathrm{mol}) ; \mathrm{TBAB}$ or other bromide $/ \mathrm{Pd}=$ $60 / 1(\mathrm{~mol} / \mathrm{mol}) ; T=100^{\circ} \mathrm{C} ; P=60 \mathrm{~atm}\left(\mathrm{CO} / \mathrm{O}_{2}=10 / 1\right)$.

systems, each cluster is surrounded by a monomolecular layer of ammonium salt which thus functions as a stabiliser and prevents undesirable metal formation. This colloidal dispersion is easily produced when the surfactant concentration is higher than the critical micelle concentration [27]. The formation of these $\mathrm{Pd}(0)$ nanostructures is important because, under the reaction conditions, the $\mathrm{R}_{4} \mathrm{~N}^{+} \mathrm{X}^{-}$-stabilised clusters can be easily reoxydized as hypothesized in the catalytic cycle. When the TBAB concentration is lower than that required for the formation of micelles, the presence of palladium metal is observed at the end of the reaction. Under these conditions, the catalyst productivity is lower because the reoxidation of the metal powder is slower. This can be the reason why the highest productivity is achieved when the molar ratio $\mathrm{TBAB} / \mathrm{Pd}$ is higher than $40 / 1$.

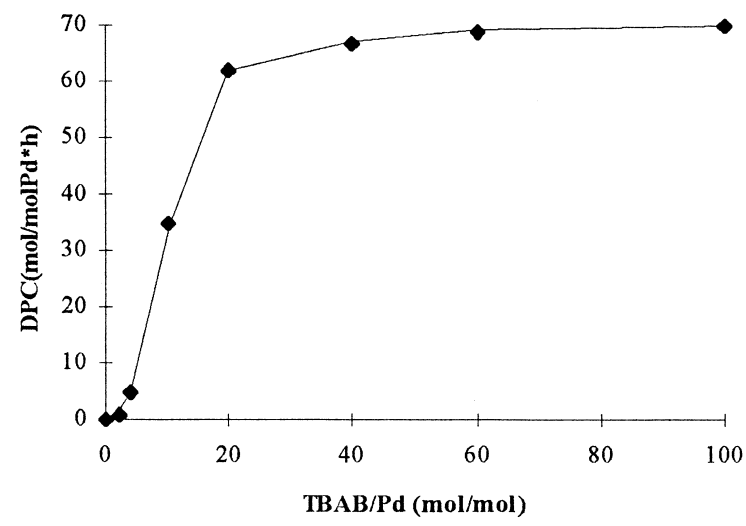

Fig. 1. Effect of TBAB/Pd molar ratio on the productivity. 




Fig. 2. Productivity as function of BQ/Pd molar ratio, in the absence of any metal cocatalyst.

3.3. Effect of $B Q$ or of a metal cocatalyst on the productivity of the $\mathrm{Pd}(\mathrm{OAc})_{2} / \mathrm{TBAB}$ based catalytic system

All the experiments were carried out employing the $\mathrm{Pd}(\mathrm{OAc})_{2} / \mathrm{TBAB}$ in the ratio $1 / 60$. Fig. 2 shows that upon adding $\mathrm{BQ}$, the productivity increases to reach a plateau value of $(35 \mathrm{~mol} \mathrm{DPC} / \mathrm{mol}$ $\mathrm{Pd} h$ ) when the ratio $\mathrm{BQ} / \mathrm{Pd}$ is $20 / 1$.

The effect of $\mathrm{Co}, \mathrm{Mn}$, or $\mathrm{Cu}$ metal cocatalyst on the activity of a $\mathrm{Pd} / \mathrm{TBAB}$ system is reported in Tables 4-6, respectively.

With cobalt, the highest productivity $(69 \mathrm{~mol} \mathrm{DPC} / \mathrm{mol} \mathrm{Pd} \mathrm{h}$, entry 3 ) is obtained using Co(III) acetylacetonate $\left(\mathrm{Co}(\mathrm{acac})_{3}\right)$. Note that with $\mathrm{Co}(\mathrm{OAc})_{2}(45 \mathrm{~mol} \mathrm{DPC} / \mathrm{mol} \mathrm{Pd} \mathrm{h}$, entry 1) and with

Table 4

Effect of the addition of different Co compounds on the productivity

\begin{tabular}{rllll}
\hline Entry & Catalyst & $\begin{array}{l}\text { Metal } \\
\text { cocatalyst }\end{array}$ & $\begin{array}{l}p \text {-BQ/Pd } \\
(\mathrm{mol} / \mathrm{mol})\end{array}$ & $\begin{array}{l}\text { Productivity } \\
(\mathrm{mol} \mathrm{DPC} / \mathrm{mol} \mathrm{Pd} \mathrm{h})\end{array}$ \\
\hline 1 & $\mathrm{Pd}(\mathrm{OAc})_{2}$ & $\mathrm{Co}(\mathrm{OAc})_{2}$ & 30 & 50 \\
2 & $\mathrm{Pd}(\mathrm{benz})_{2}$ & $\mathrm{Co}(\mathrm{OAc})_{2}$ & 30 & 45 \\
3 & $\mathrm{Co}(\mathrm{acac})_{3}$ & 30 & 69 & 67 \\
4 & $\mathrm{Pd}(\mathrm{OAc})_{2}$ & $\mathrm{Co}(\mathrm{acac})_{3}$ & 30 & 41 \\
5 & $\mathrm{Pd}(\mathrm{benz})_{2}$ & $\mathrm{Co}(\mathrm{benz})_{2}$ & 30 & 38 \\
6 & $\mathrm{Pd}(\mathrm{OAc})_{2}$ & $\mathrm{Co}(\mathrm{benz})_{2}$ & 30 & 12 \\
7 & $\mathrm{Pd}(\mathrm{benz})_{2}$ & $\mathrm{Co}(\mathrm{salen})_{2}$ & 30 & 11 \\
8 & $\mathrm{Pd}(\mathrm{OAc})_{2}$ & $\mathrm{Co}(\mathrm{picO})_{2}$ & 30 & 35 \\
9 & $\mathrm{Pd}(\mathrm{OAc})_{2}$ & $\mathrm{Co}(\mathrm{pic})_{2}$ & 30 & 30 \\
10 & $\mathrm{Pd}(\mathrm{OAc})_{2}$ & $\mathrm{Co}(\mathrm{OAc})_{2}$ & - & 15 \\
11 & $\mathrm{Pd}(\mathrm{OAc})_{2}$ & $\mathrm{Co}(\mathrm{acac})_{3}$ & - & 3 \\
13 & $\mathrm{Pd}(\mathrm{OAc})_{2}$ & $\mathrm{Co}(\mathrm{acac})_{3}$ & - & 5 \\
14 & $\mathrm{Pd}(\mathrm{benz})_{2}$ & $\mathrm{Co}(\mathrm{benz})_{2}$ & - & 5 \\
16 & $\mathrm{Pd}(\mathrm{OAc})_{2}$ & $\mathrm{Co}(\mathrm{salen})_{2}$ & - & - \\
\hline
\end{tabular}

$\mathrm{Pd}(\mathrm{II})=0.01 \mathrm{mmol} ; \mathrm{PhOH}=80 \mathrm{mmol} ; \mathrm{TBAB} / \mathrm{Pd}=60 / 1(\mathrm{~mol} / \mathrm{mol}) ;$ metal cocatalyst $/ \mathrm{Pd}(\mathrm{II})=3 / 1(\mathrm{~mol} / \mathrm{mol}) ; T=100^{\circ} \mathrm{C} ; P=60$ atm $\left(\mathrm{CO} / \mathrm{O}_{2}=10 / 1\right)$; reaction time $=5 \mathrm{~h}$. 
Table 5

Effect of the addition of different Mn compounds on the productivity

\begin{tabular}{rllll}
\hline Entry & Catalyst & Cocatalyst & $\begin{array}{l}p \text {-BQ/Pd } \\
(\mathrm{mol} / \mathrm{mol})\end{array}$ & $\begin{array}{l}\text { productivity } \\
(\mathrm{mol} \mathrm{DPC} / \mathrm{mol} \mathrm{Pd} \mathrm{h})\end{array}$ \\
\hline 1 & $\mathrm{Pd}(\mathrm{OAc})_{2}$ & $\mathrm{Mn}(\mathrm{OAc})_{2}$ & 30 & 32 \\
2 & $\mathrm{Mn}(\mathrm{acac})_{3}$ & 30 & 48 \\
3 & $\mathrm{Mn}(\mathrm{picO})_{2}$ & 30 & 5 \\
4 & $\mathrm{Pd}(\mathrm{OAc})_{2}$ & $\mathrm{Mn}(\mathrm{chin})_{2}$ & 30 & 5 \\
5 & $\mathrm{Pd}(\mathrm{OAc})_{2}$ & $\mathrm{Mn}(\mathrm{pic})_{2}$ & 30 & 10 \\
6 & $\mathrm{Pd}(\mathrm{OAc})_{2}$ & $\mathrm{Mn}(\mathrm{OAc})_{2}$ & - & 18 \\
7 & $\mathrm{Pd}(\mathrm{OAc})_{2}$ & $\mathrm{Mn}(\mathrm{acac})_{3}$ & - & trace \\
8 & $\mathrm{Pd}(\mathrm{OAc})_{2}$ & $\mathrm{Mn}(\mathrm{picO})_{2}$ & - & 30 \\
9 & $\mathrm{Pd}(\mathrm{OAc})_{2}$ & $\mathrm{Mn}(\mathrm{chin})_{2}$ & - & 46 \\
10 & $\mathrm{Pd}(\mathrm{OAc})_{2}$ & $\mathrm{Mn}(\mathrm{pic})_{2}$ & 30 & 18 \\
11 & $\mathrm{Pd}(\mathrm{OAc})_{2}$ & $\mathrm{Mn}(\mathrm{OAc})_{2}$ & 30 & - \\
13 & $\mathrm{Pd}(\mathrm{benz})_{2}$ & $\mathrm{Mn}(\mathrm{acac})_{3}$ & - & \\
\hline
\end{tabular}

$\mathrm{Pd}(\mathrm{II})=0.01 \mathrm{mmol} ; \mathrm{PhOH}=80 \mathrm{mmol} ; \mathrm{TBAB} / \mathrm{Pd}=60 / 1(\mathrm{~mol} / \mathrm{mol}) ;$ metal cocatalyst $/ \mathrm{Pd}(\mathrm{II})=3 / 1(\mathrm{~mol} / \mathrm{mol}) ; T=100^{\circ} \mathrm{C} ; P=60$ atm $\left(\mathrm{CO} / \mathrm{O}_{2}=10 / 1\right)$; reaction time $=5 \mathrm{~h}$.

other Co compounds, which are very active in the analogous dimethyl carbonate synthesis, for example, $\mathrm{Co}($ salen$\left.), \mathrm{Co}(\text { pic })_{2}\right)[22,23]$, the productivity is significantly lower. Table 4 shows that these metal compounds are effective as cocatalyst also in the absence of BQ (experiments 10-16), but the productivity is lower when the two oxidants were used together. Also, in these cases, the synergic effects observed in Table 2 are confirmed. For instance, in Table 3, entry 10, using $\mathrm{Pd}(\mathrm{OAc})_{2}$, with $\mathrm{BQ}$ alone, the productivity obtained is $30 \mathrm{~mol} \mathrm{DFC} / \mathrm{mol} \mathrm{Pd} \mathrm{h}$, with $\mathrm{Co}(\mathrm{acac})_{3}$ alone is $35 \mathrm{~mol}$ $\mathrm{DFC} / \mathrm{mol} \mathrm{Pd} \mathrm{h}$ (Table 4, entry 11) but, when the two cocatalyst are used together, the productivity is $69 \mathrm{~mol} \mathrm{DFC} / \mathrm{mol} \mathrm{Pd} \mathrm{h}$ (Table 4, entry 3).

Also, several Mn compounds (see Table 5) are active as cocatalysts even though less than Co complexes. The highest productivity observed has been obtained using $\mathrm{Mn}(\mathrm{acac})_{3}$ in combination with BQ (48 mol DPC/mol Pd h, entry 2).

$\mathrm{A} \mathrm{Cu}(\mathrm{II})$ compound, $\mathrm{Cu}(\mathrm{acac})_{2}$ (see Table 6), in combination with an excess of $\mathrm{BQ}$, leads to the best results in terms of productivity $(89 \mathrm{~mol} \mathrm{DPC} / \mathrm{mol} \mathrm{Pd} \mathrm{h}$ ), however, when the selectivity is lower.

Table 6

Effect of the addition of different $\mathrm{Cu}$ compounds on the productivity

\begin{tabular}{rllll}
\hline Entry & Catalyst & Cocatalyst & $\begin{array}{l}p \text {-BQ/Pd } \\
(\mathrm{mol} / \mathrm{mol})\end{array}$ & $\begin{array}{l}\text { Productivity } \\
(\mathrm{mol} \mathrm{DPC} / \mathrm{mol} \mathrm{Pd} \mathrm{h})\end{array}$ \\
\hline 1 & & $\mathrm{CuCl}_{2}$ & 30 & 16 \\
2 & $\mathrm{Pd}(\mathrm{OAc})_{2}$ & $\mathrm{Cu}(\mathrm{acac})_{2}$ & 30 & 89 \\
3 & $\mathrm{Pd}(\mathrm{OAc})_{2}$ & $\mathrm{Cu}(\mathrm{OAc})_{2}$ & 30 & 66 \\
4 & $\mathrm{Pd}(\mathrm{OAc})_{2}$ & $\mathrm{Cu}(\mathrm{acac})_{2}$ & 30 & 15 \\
5 & $\mathrm{Pd}(\mathrm{benz})_{2}$ & $\mathrm{Cu}(\mathrm{acac})_{2}$ & 30 & 6 \\
6 & $\mathrm{Pd}(\mathrm{acac})_{2}$ & $\mathrm{CuCl})_{2}$ & - & 34 \\
7 & $\mathrm{Pd}(\mathrm{OAc})_{2}$ & $\mathrm{Cu}(\mathrm{acac})_{2}$ & - & 21 \\
8 & $\mathrm{Pd}(\mathrm{OAc})_{2}$ & $\mathrm{Cu}(\mathrm{OAc})_{2}$ & - & 31 \\
9 & $\mathrm{Pd}(\mathrm{OAc})_{2}$ & $\mathrm{Cu}(\mathrm{acac})_{2}$ & - & 15 \\
10 & $\mathrm{Pd}(\mathrm{benz})_{2}$ & $\mathrm{Cu}(\mathrm{acac})_{2}$ & - & trace \\
\hline
\end{tabular}

$\mathrm{Pd}(\mathrm{II})=0.01 \mathrm{mmol} ; \mathrm{PhOH}=80 \mathrm{mmol} ; \mathrm{TBAB} / \mathrm{Pd}=60 / 1(\mathrm{~mol} / \mathrm{mol}) ;$ metal cocatalyst $/ \mathrm{Pd}(\mathrm{II})=3 / 1(\mathrm{~mol} / \mathrm{mol}) ; T=100^{\circ} \mathrm{C} ; P=60 \mathrm{~atm}$ $\left(\mathrm{CO} / \mathrm{O}_{2}=10 / 1\right)$; reaction time $=5 \mathrm{~h}$. 




Fig. 3. Effect of the $\mathrm{Co}(\mathrm{acac})_{3} / \mathrm{Pd}(\mathrm{OAc})_{2}$ molar ratio on the productivity.

Phenylsalicylate and oligomeric compounds are the main side products, ca. $10 \%$ with respect DPC, vs. ca. $1 \%$ when $\mathrm{Co}$ or $\mathrm{Mn}$ are used.

\subsection{Optimization of the $\mathrm{Pd}(\mathrm{OAc})_{2} / \mathrm{TBAB} / \mathrm{Co}(\mathrm{acac})_{3} / \mathrm{BQ}$ catalytic system}

We attempted to optimise the performance of the best catalyst/cocatalyst system $\left(\mathrm{Pd}(\mathrm{OAc})_{2} / \mathrm{Co}(\mathrm{acac})_{3} / \mathrm{BQ} / \mathrm{TBAB}\right)$, maintaining $\mathrm{BQ} / \mathrm{Pd}(30 / 1)$ and $\mathrm{TBAB} / \mathrm{Pd}(60 / 1)$ constant.

As shown in Fig. 3, the highest productivity is obtained when a molar ratio $\mathrm{Co} / \mathrm{Pd}=2 / 1-3 / 1$ is used. The productivity does not increase with further increasing of the Co concentration, reaching the

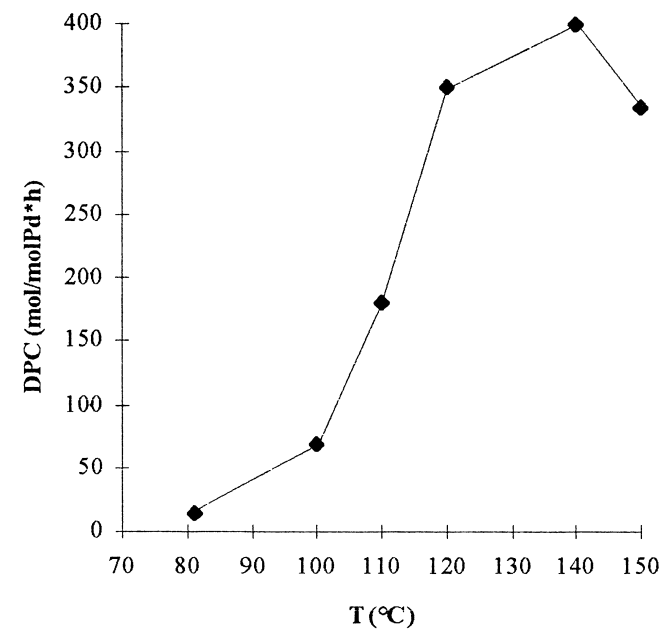

Fig. 4. Effect of the reaction temperature on the productivity. 
plateau for $\mathrm{Co} / \mathrm{Pd}>3 / 1\left(70 \mathrm{~mol} \mathrm{DPC} / \mathrm{mol} \mathrm{Pd} \mathrm{h}\right.$ at $90^{\circ} \mathrm{C}$ and $400 \mathrm{~mol} \mathrm{DPC} / \mathrm{mol} \mathrm{Pd} \mathrm{h}$ at $\left.140^{\circ} \mathrm{C}\right)$. It is interesting to note that this ratio is close to the stoichiometry of the redox reaction (5) of the proposed catalytic cycle.

\subsection{Effect of the temperature}

The productivity reaches the maximum value (400 mol DPC $/ \mathrm{mol} \mathrm{Pd}$ ) at $140^{\circ} \mathrm{C}$ (see Fig. 4). The lowering in the productivity, observed upon increasing the temperature above $140^{\circ} \mathrm{C}$, is probably due to side reactions of $\mathrm{BQ}$ with phenol which yields complicated mixtures containing dimeric, trimeric compounds and polymers [29]. As a matter of fact, a large amount of a brown polymer, together with $\mathrm{Pd}$ metal, is found at the end of the reaction above $140^{\circ} \mathrm{C}$.

\section{Abbreviations}

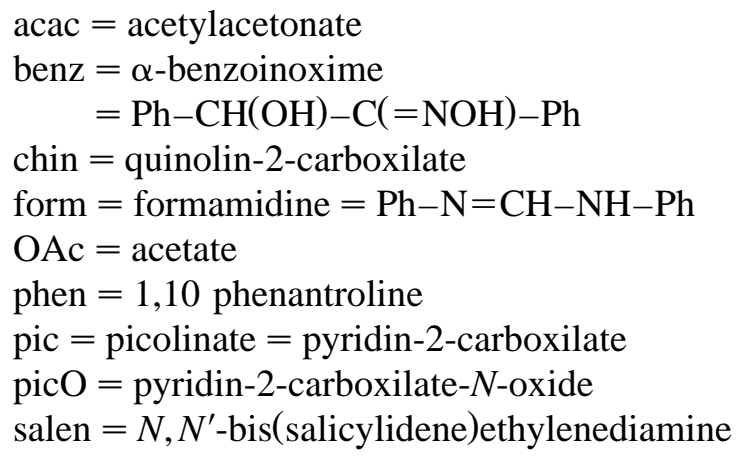

\section{Acknowledgements}

This work was carried out with the financial support of the Ministero della Ricerca Scientifica e Tecnologica, Programma Nazionale di Ricerca per la Qualita’ della Vita.

\section{References}

[1] A.G. Shaikh, S. Sivaram, Chem. Rev. 96 (1996) 951.

[2] Y. Ono, Pure Appl. Chem. 68 (1996) 367.

[3] U. Romano, R. Tesei, M. Massi Mauri, P. Rebora, Ind. Eng. Chem. Prod. Res. Dev. 19 (1980) 396.

[4] A.G. Shaikh, S. Sivaram, Ind. Eng. Chem. Res. 31 (1992) 1167.

[5] M. Graziani, P. Uguagliati, G. Carturan, J. Organomet. Chem. 27 (1971) 275.

[6] G. Cavinato, L. Toniolo, J. Organomet. Chem. 444 (1993) C65.

[7] F. Rivetti, U. Romano, J. Organomet. Chem. 154 (1978) 323.

[8] F. Rivetti, U. Romano, J. Organomet. Chem. 174 (1979) 221.

[9] D.M. Fenton, J. Steinwand, J. Org. Chem. 39 (1974) 701.

[10] R.A. Lucky, G.E. Morris, British Petroleum, EP 220863 A1, 1987.

[11] J.E. Hallgren, R.O. Matthews, J. Organomet. Chem. 175 (1979) 135.

[12] J.E. Hallgren, G.M. Lucas, R.O. Matthews, J. Organomet. Chem. 204 (1981) 135.

[13] I.I. Moiseev, M.N. Vargaftik, T.V. Chernysheva, T.A. Stromnova, A.E. Gekhman, G.A. Tsirkov, A.M. Makhlina, J. Mol. Catal. 108 (1996) 77. 
[14] I.I. Moiseev, T.A. Stromnova, M.N. Vargaftik, J. Mol. Catal. 86 (1994) 71.

[15] A. Heumann, K.J. Jens, M. Reglier, Prog. Inorg. Chem. 42 (1994) 542-556.

[16] T.C.-T. Chang, General Electric, EP 0350697 A2, 1990.

[17] M. Mizukami, K. Hayashi, Mitsubishi Gas Chemical, EP 0572980 A2, 1993.

[18] H. Kezuka, F. Okuda, Idemitsu Kosan, EP 0503581 A2, 1992.

[19] T.C.-T. Chang, General Electric, EP 350700 A2, 1990.

[20] J.A. King, T.E. Krafft, G.R. Faler, General Electric, US 5142086, 1991.

[21] J.A. King, General Electric, EP 450442 A1, 1991.

[22] D. Delledonne, F. Rivetti, U. Romano, EP 463678 A, 1991.

[23] D. Delledonne, F. Rivetti, U. Romano, J. Organomet. Chem. 488 (1995) C15.

[24] H. Grennberg, A. Gogoll, J.E. Backvall, Organometallics 12 (1993) 1790.

[25] H. Bonnemann, W. Brijoux, R. Brinkmann, E. Dinjus, T. Joussen, B. Korall, Angew. Chem., Int. Ed. Engl. 30 (1991) 1312.

[26] M.T. Reetz, W. Helbig, S.A. Quaiser, U. Stimming, N. Breuer, R. Vogel, Science 267 (1995) 367.

[27] N. Toshima, T. Takahashi, Bull. Chem. Soc. Jpn. 65 (1992) 400.

[28] J. Kiwi, M. Gratzel, J. Am. Chem. Soc. 101 (1979) 7214.

[29] H. Musso, Angew. Chem., Int. Ed. 2 (1963) 723. 